\title{
Por Matemática(s) Decoloniais: vozes que vêm da escola
}

\author{
For decolonial mathematics: Voices that come from school
}

Diego Matos*

ORCID iD 0000-0002-7208-3226

Victor Giraldo**

ORCID iD 0000-0002-2246-6798

Wellerson Quintaneiro***

ORCID iD 0000-0001-8723-0033

\begin{abstract}
Resumo
Este artigo tem como objetivo discutir experiências de estudantes da Educação Básica com matemática(s) mobilizadas na escola, a partir de uma opção decolonial. Os dados foram produzidos por meio de redações e desenhos sobre a matemática escolar, feitos por estudantes do $1^{\circ}$ ano do Ensino Médio de uma escola pública federal da cidade do Rio de Janeiro. O uso de uma metodologia qualitativa baseada na análise do discurso possibilitou a produção de resultados indicando manifestações de resistência que denunciam traços e efeitos de colonialidade do poder, do saber e do ser no ensino de matemática(s) na escola básica. Comunicamos os resultados em um formato narrativo ficcional, em que esses três eixos da colonialidade, além da decolonialidade, são apresentados por quatro personagens que encarnam as vozes dos estudantes em forma de gritos por liberdade. Essa narrativa se dá em um entrelugar em que os quatro personagens dialogam com figuras de culturas autóctones que incorporam o fio condutor desse enredo.
\end{abstract}

Palavras-chave: Matemática Escolar. Decolonialidade. Resistência. Formatos Insubordinados.

\begin{abstract}
This paper aims to discuss experiences of secondary school students with mathematics mobilized at school, from a decolonial option. The data was produced through essays and drawings on school mathematics, made by $10^{\text {th }}$ grade students from a federal public school in the city of Rio de Janeiro. The use of a qualitative methodology grounded on the analysis of the discourse enabled the production of results indicating manifestations of resistance that reveal traits and effects of coloniality of power, knowledge, and being in the teaching of basic school mathematics. We report the results in a fictional narrative. in which these three axes of coloniality, as well as movements of decoloniality, are intertwined by four characters who incarnate the students' voices, in the form of yells for freedom. This narrative happens in a in between place where the four characters dialogue with figures from indigenous cultures who embody the guiding thread of this plot.
\end{abstract}

Keywords/Palabras clave: School Mathematics. Decoloniality. Resistance. Unsubordinated formats.

\footnotetext{
* Doutor em Ensino e História da Matemática e da Física pela Universidade Federal do Rio de Janeiro (UFRJ). Professor Adjunto do Departamento de Matemática da Universidade Federal do Estado do Rio de Janeiro (UNIRIO), Rio de Janeiro, Rio de Janeiro, Brasil. E-mail: diego.matos@uniriotec.br.

** Doutor em Engenharia de Sistemas e Computação pela Universidade Federal do Rio de Janeiro (UFRJ). Professor Associado do Departamento de Matemática da Universidade Federal do Rio de Janeiro (UFRJ), Rio de Janeiro, Rio de Janeiro, Brasil. E-mail: victor.giraldo@gmail.com.

*** Doutor em Educação Matemática pela Universidade Bandeirante de São Paulo (Unian). Professor do Ensino Básico Técnico e Tecnológico do Centro Federal de Educação Tecnológica Celso Suckow da Fonseca (CEFETRJ), Nova Iguaçu, Rio de Janeiro, Brasil. E-mail: profmatwellerson@gmail.com.
} 


\section{Nos perdemos (encontramos) em seus versos}

De cálculos avançados à escrita à mão A matemática na escola é muito padrão

De tanto estudar, tirei nota baixa

Não deveria pensar fora da caixa? A lógica ensinada, importante racionalidade

Esses conceitos são realmente verdade?

O stress acumulado, decore as fórmulas

Até quando precisarei de colas?

Entre as quatro paredes não me sinto vivo

É muito para mim, sou muito subjetivo

O problema em si não é a matemática

É o método de ensino e a escola estática

Como um cavalo, me sinto na cela

Apesar de tudo, não consigo viver sem ela

Sempre terá mil saídas

Mas, não tem jeito, matemática é vida

Este poema não representa uma simples epígrafe para a temática deste artigo. Muito além disso, talvez tenhamos começado essa história por seu clímax, justamente por entendermos que tais palavras representam o cerne do que discutiremos. Inicialmente, não revelaremos sua autoria, pois consideramos que essa identidade ainda não traduz o que há de mais importante agora. Neste momento, recomendamos sentir suas palavras. Desejamos propor um exercício inicial de reflexão que te defronte com sua força, que evidencie como elas te provocam, para onde te transportam. Em paralelo, na primeira seção deste texto, descrevemos como nós - seus autores - reagimos diante dessas e de outras palavras, expressando como elas nos deslocaram do lugar onde nos encontrávamos. Embora não sejamos autores do poema, tampouco porta-vozes dessa gente, devemos confessar: nos perdemos (encontramos) em seus versos. "O problema em si não é a matemática / É o método de ensino e a escola estática". Ficamos impactados ao reconhecermos que esses e outros versos sintetizam grande parte das reflexões, discussões, investigações e lutas em nosso grupo de pesquisa, o Laboratório de Práticas Matemáticas do Ensino - LaPraME.

Como deixamos os estudantes da escola básica de fora dessa discussão por tanto tempo? Por que não estavam presentes em nossas pesquisas se pensávamos, a todo momento, em quem os formaria, os educaria por meio das matemática(s) ${ }^{1}$ ? É preciso que suas falas

\footnotetext{
${ }^{1}$ A palavra "matemática", no singular, é frequentemente associada a um corpo único de conhecimento imutável, evolutivo e constituído a partir de produções científicas de matemáticos pesquisadores. A opção pelo termo "matemática(s)", no plural, demarca um posicionamento político que se opõe a essa história única - e eurocêntrica - de conhecimento, indicando nosso reconhecimento do dinamismo e da diversidade dos processos históricos e sociais que atravessam a produção de saberes matemáticos. Além disso, a opção pelo uso dos parênteses nessa
} 
ultrapassem os muros da escola, que deixem de ser silenciadas e sejam ouvidas por mais gente. Não precisamos falar por vocês, suas palavras têm força!

Considerando os saberes matemáticos para o ensino como dinâmicos e emergentes de práticas mobilizadas por estudantes e professores na escola básica, o primeiro autor deste artigo, compreendendo sua própria prática docente a partir de uma postura investigativa intencional (COCHRAN-SMITH; LYTLE, 2009), buscou investigar, como parte de sua pesquisa de doutorado $^{2}$ (MATOS, 2019), a questão: Como experiências de estudantes da Educação Básica podem revelar (ou produzir) espaços de resistência a relações de colonialidade associadas a matemática(s) mobilizadas em contextos institucionais formativos na escola básica?

Os dados foram produzidos a partir de redações e desenhos feitos por estudantes de seis turmas do $1^{\mathrm{o}}$ ano do Ensino Médio de uma escola pública federal ${ }^{3}$ da cidade do Rio de Janeiro, cada uma com cerca de 35 estudantes, das quais o primeiro autor deste artigo era professor de matemática(s) quando a pesquisa foi realizada. No primeiro dia de aula de dois anos letivos consecutivos (2017 e 2018), foi proposto aos estudantes que escrevessem uma redação com tema: Qual é a sua visão sobre a Matemática ensinada na escola durante o Ensino Fundamental, desde seu início no $1^{\circ}$ ano até sua conclusão no $9^{\circ}$ ano? Como tarefa para ser entregue na aula seguinte, os estudantes deveriam produzir um desenho que sintetizasse o que haviam escrito em sala de aula. Em ambos os casos, foi recomendado que as produções fossem anônimas.

As redações, como formas discursivas, representavam, na perspectiva de Larrosa (2004), narrativas por meio das quais os estudantes vão dando sentido a suas experiências, construindo suas histórias e, assim, constituindo e significando quem são e quem são os outros. Logo na primeira turma em que a atividade foi solicitada, um estudante questionou: "Posso fazer um poema?". Após breves minutos de escrita, o mesmo estudante levantou-se e entregou sua redação ao professor fazendo o seguinte pedido: "Quero que você leia! Não tem problema

construção visa evidenciar uma tensão permanente entre a imposição de epistemologias únicas e a (re)existência de sabedorias plurais - em consonância com a posição demarcada por Walsh (2013), com o uso do termo decolonialidade (em vez de descolonialidade), de que não existe um estado neutro de colonialidade, como se fosse possível passar de um regime colonial para um livre de seus traços e efeitos. Portanto, a opção por esse termo expressa nossa opção política por movimentos permanentes de luta, resistência e insurgência.

2 Resultados de uma investigação sobre questões semelhantes, agora com estudantes de Licenciatura em Matemática no contexto da formação de professores, que integra a mesma pesquisa de doutorado, são comunicados em Matos e Quintaneiro (2019) e em Giraldo, Matos e Quintaneiro (2021).

${ }^{3} \mathrm{O}$ nome da escola não será revelado por questões de preservação de sigilo. Os responsáveis legais de todos os estudantes participantes da produção dos dados usados neste artigo assinaram termos de consentimento livre e esclarecido concordando com as condições da pesquisa, assim como os estudantes também assinaram termos de assentimento livre e esclarecido. Reforçamos, ainda, que a investigação foi apreciada e aprovada em Comitê de Ética em Pesquisa. 
me identificar. Eu assinei, inclusive". Após a leitura do professor, a evidente conclusão: de fato, não era preciso muito tempo. Estava tudo ali, sempre esteve. Bastava deixá-los se manifestarem e ouvi-los. O autor do poema que inicia este artigo é Felipe (nome fictício). Ao se aproximar e buscar conhecê-lo um pouco mais, o professor é surpreendido novamente: "Professor, eu estou refazendo o $1^{\circ}$ ano. Uma das matérias que eu repeti foi matemática".

Não sabemos como o poema de Felipe te provocou até este instante, mas reforçamos, mais uma vez, como nos perdemos (encontramos) em seus versos. Versos que nos provocaram ao ponto de nos transportarem para outro lugar: "Entre as quatro paredes não me sinto vivo / É muito para mim, sou muito subjetivo". Um lugar onde as vozes anônimas presentes nas redações e desenhos ilustrarão manifestações de resistência em experiências com matemática(s) vivenciadas na escola básica. Tais manifestações - anônimas, mas que falam por tanta gente se juntam aos versos de Felipe, dando forma a vozes que vêm da escola. Convidamos para que venha até esse lugar se perder (encontrar) conosco.

\section{Andanças em um lugar desconhecido}

Ainda não sabemos onde estamos, tampouco aonde tentamos chegar ou por que caminhos seguir. Porém, para encontrar seus atalhos, nos vimos desafiados a nos insubordinar e a nos desprender dos formatos acadêmicos convencionais que, por vezes, nos aprisionam em nossas pesquisas. A natureza dos dados produzidos nos confrontou com um dilema metodológico, a partir de uma reflexão sobre que sentidos tais lentes convencionais poderiam invisibilizar. Nesta pesquisa, o formato de apresentação é parte de seu conteúdo, isto é, não se limita a uma forma de comunicar resultados produzidos a priori, mas é constituinte dos próprios resultados. Portanto, adotar um formato insubordinado não representa apenas uma opção relativa à forma, mas um posicionamento teórico-metodológico inerente ao seu conteúdo (BARBOSA, 2015). Inspiramo-nos no formato narrativo por acreditarmos que um de seus propósitos “é substituir o “conforto’ pela 'provocação”” (BARBOSA, 2015, p. 360).

Mergulhando nas 119 redações e nos 98 desenhos produzidos, reconhecemos manifestações de resistência em experiências com matemática(s) na escola. Essas expressões das experiências dos estudantes nos movem ao encontro de outros grupos silenciados e subalternizados por poderes hegemônicos, remetendo a processos de colonização de sabedorias 
e de corpos, tais como aqueles sofridos pelos povos autóctones ${ }^{4}$ das terras que hoje formam o Brasil - processos marcados pela tomada do território após seu "descobrimento" e pela violação de suas formas de estar no mundo, por meio da imposição de culturas eurocêntricas, legitimadas pela missão de "civilizar" aqueles povos tidos como "bárbaros" ou "atrasados".

Ao transitarmos na direção do encontro entre culturas autóctones e experiências vivenciadas pelos estudantes com matemática(s) na escola básica, não pretendemos estabelecer comparações entre essas coletividades, mesmo porque, no Brasil, não vivenciamos mais o colonialismo, definido aqui como uma "relação política e econômica, na qual a soberania de um povo está no poder de outro povo ou nação, o que constitui a referida nação em um império" (MALDONADO-TORRES, 2007, p. 131, tradução nossa).

Diferentemente do colonialismo, o encontro inesperado com os povos autóctones em nossa história denuncia algo ainda presente nos tempos atuais: a colonialidade. MaldonadoTorres (2007) nos descreve que a colonialidade não está limitada a relações formais de subordinação entre povos ou nações, mas se refere a um padrão de poder que sobrevive ao colonialismo, emergindo nas formas como o trabalho, o conhecimento, a autoridade e as relações intersubjetivas se manifestam e se articulam entre si.

Mais ainda, as andanças que nos levam ao encontro com povos autóctones nos ajudam, nesta caminhada, a chegar a outros lugares, juntando-se a essas vozes que vêm da escola. Nessa perspectiva, evocamos as vozes dos povos autóctones a partir de duas fontes principais: (1) mensagem do Cacique Raoni da etnia Kayapó e carta escrita por autóctones das etnias Xavante e Mehinaku em 2000, enviada aos presidentes de Brasil e Portugal, na época, Fernando Henrique Cardoso e Jorge Sampaio, por ocasião da "comemoração" dos 500 anos do "descobrimento" do Brasil"; (2) enredo e samba-enredo "Xingu - o Clamor que Vem da Floresta", da G.R.E.S. Imperatriz Leopoldinense no Carnaval do Rio de Janeiro de 2017, que homenageia os autóctones xinguanos e os 55 anos do Parque Nacional do Xingu ${ }^{6}$. Em

\footnotetext{
${ }^{4}$ Optamos por usar o termo autóctone - que significa originário do território -, em lugar dos termos convencionais "índio" ou "indígena", por considerarmos que esses últimos remetem a sentidos que desqualificam os povos nativos e suas culturas, desconsiderando as diversidades que as caracterizam e lhes atribuindo conotações de generalidade e atraso. Consideramos que o termo autóctone reafirma a ideia de que tais povos são os naturais do território - habitantes originais e não os invasores -, que preservam identidades plurais e próprias.

${ }^{5}$ A íntegra da carta estava disponível em: <http://brazil.indymedia.org/content/2004/01/272987.shtml>, em acesso em 27 de julho de 2018, ocasião da realização da pesquisa de doutorado de que este trabalho faz parte. Entretanto, ao buscá-la novamente para elaboração deste texto, não fomos capazes de encontrar a carta na íntegra nesse ou em qualquer sítio da internet de acesso livre. Trechos da carta estão disponíveis em: <https://jornalistaslivres.org/ascartas-dos-povos-indigenas-ao-brasil/> (acesso em: 24 de fevereiro de 2020). Tal "desaparecimento" pode ser interpretado como traços do silenciamento de vozes autóctones, característico da colonialidade.

${ }^{6}$ A sinopse do enredo da G.R.E.S. Imperatriz Leopoldinense no Carnaval do Rio de Janeiro de 2017 está disponível em: <http://liesa.globo.com/2019/por/18-outroscarnavais/carnaval17/enredos/imperatriz.html>. Letra do samba
} 
particular, o enredo e samba-enredo da Imperatriz Leopoldinense não expressam falas diretas dos povos autóctones, mas incorporam formas por meio das quais suas vozes reverberam em outros lugares e em outros sujeitos, assim como, neste caso, ecoam em nossas experiências e se encarnam em nossos sentidos e afetos.

Considerando a intenção de materializar um fio condutor que entrelace os caminhos diversos que compuseram nossas andanças, essas fontes não foram selecionadas a partir de critérios convencionais de rigor etnográfico ou historiográfico, mas a partir daqueles que atravessam as experiências e permeiam os afetos dos autores deste texto - afetos provocados pelas próprias vozes dos estudantes participantes e autores desta história, expressas em escritos e desenhos cujos atravessamentos nos deslocaram do lugar onde estávamos. Assim, representados nessas escolhas, abrimos mão dos lugares convencionais de neutralidade ou de exterioridade em relação à pesquisa e nos posicionamos no interior desta narrativa, como coautores e, ao mesmo tempo, atores que dialogam com os estudantes e com os autóctones. Seguindo os conselhos de Leggo e Sameshima (2014, p. 543), buscamos, nos diálogos com essas vozes, narrar uma história que "mostre, não apenas diga".

Autóctones: Estamos aqui com toda verdade de nossa Tradição. Sem rancor, sem raiva. Mas, também não estamos comemorando nada. Esta não é nossa comemoração. Apesar de toda distância e dificuldade, viemos porque temos que falar com vocês. Estamos aqui para fazer um novo contato.

(Carta dos autóctones das etnias Xavante e Mehinaku, 2000).

A fala dos autóctones diante dos estudantes nos mostra o encontro e o entrelaçamento de diferentes caminhos, anunciando que chegamos ao lugar para o qual as palavras de Felipe nos transportavam. Porém, ainda tentamos identificar onde estamos. Que lugar é esse, então? Bhabha (1998) nos mostra que o lugar fronteiriço entre culturas exige um encontro com o "novo", que não seja parte de uma linearidade entre passado e presente, refigurando-o como um entrelugar que interrompe a atuação do presente, de maneira que o passado-presente tornase parte da necessidade - e não da nostalgia - de viver. É nesse entrelugar que nos encontramos, onde se pode atravessar pelo inconsciente do outro, onde ocorre o sincretismo de culturas, onde elas acontecem como são, constituindo lugares de enunciação onde compartilham suas sabedorias, suas dores e apontam caminhos para sua (re)existência. Nesse sentido, entendemos que há um diálogo que se realiza no encontro entre as vozes que ecoam da escola e das manifestações dos autóctones aqui abordadas.

disponível em: <http://liesa.globo.com/2019/por/18-outroscarnavais/carnaval17/sambasenredo/imperatriz.html>. Acessos em: 24 de fevereiro de 2020. 
O encontro entre essas coletividades - estudantes da escola básica e povos autóctones evidencia denúncias que ecoam de lugares distintos, que são reivindicadas por vozes diferentes, mas que se intersectam ao sofrerem formas de silenciamento instauradas a serviço de um projeto de poder colonial. Assim, como destacamos em Giraldo, Fernandes, Matos e Quintaneiro (2020), a intersecção dessas denúncias expõe formas por meio das quais traços e efeitos da colonialidade se capilarizam tanto em uma dimensão macropolítica - nas hierarquias sociais baseadas em categorias como raça e gênero, nas estruturas de conhecimento, autoridade e trabalho - como em uma dimensão micropolítica - nas relações interpessoais e intersubjetivas. As vozes que vêm da escola, em diálogo com povos autóctones, nos fazem refletir sobre o papel que a Matemática, como disciplina escolar, tem desempenhado nesse projeto de poder colonial - silenciando saberes e confinando seres em lugares sociais subalternizados.

Do lugar onde agora nos encontramos, notamos a companhia de outros pesquisadores que nos ajudam a mediar esse encontro e a fundamentar nosso diálogo. Walsh (2008) destaca pelo menos três eixos entrelaçados em que a colonialidade se manifesta: a colonialidade do poder, a colonialidade do saber, a colonialidade do ser. A autora nos alerta, também, que junto com a colonialidade emerge a decolonialidade, não somente como uma forma de resistir, mas de sustentar e (re)construir (WALSH, 2017). Buscamos, então, nas redações e desenhos dos estudantes, manifestações de resistência em suas experiências com matemática(s) na escola. Identificamos traços de, pelo menos, um dos eixos da colonialidade descritos por Walsh (2008) em 43 redações e 28 desenhos, delimitando um recorte no corpus de dados.

Cada eixo da colonialidade, juntamente com a decolonialidade, serão aqui apresentados como gritos por liberdade ${ }^{7}$ enunciados por quatro personagens fictícios. Dessa maneira, os eixos teóricos da colonialidade do poder, do saber e do ser são denunciados pelos três personagens iniciais de nossa história: Alex, Davi e Vitória. Nosso último personagem Janaína -, nos apresenta a pedagogia decolonial como "um caminho de luta contínuo no qual podemos identificar, tornar visível e encorajar 'lugares' de exterioridade e construções alter(n)ativas" (WALSH, 2013, p. 25, tradução nossa). Cada personagem encarna um desses eixos ao expressar falas de diferentes estudantes, extraídas (com as palavras originais) de 19 redações do recorte de dados - personificando, assim, as vozes que vêm da escola.

Alex brada: "Sou guerreiro imortal derradeiro, deste chão o senhor verdadeiro!". Seu brado denuncia a colonialidade do poder, descrita por Quijano (2000) em meio ao estabelecimento de um sistema de classificação social, baseado na ideia de "raça", que impõe

\footnotetext{
${ }^{7}$ Os gritos por liberdade de nossos quatro personagens, que nomeiam as seções seguintes, são versos extraídos do samba-enredo da G.R.E.S. Imperatriz Leopoldinense no Carnaval do Rio de Janeiro de 2017.
} 
uma hierarquia de seres, saberes e visões de mundo como parte de um projeto civilizatório eurocêntrico de dominação e exploração, cujo eixo é o capital.

"O belo monstro rouba a terra dos seus filhos!", diz Davi ao nos alertar sobre a colonialidade do saber, definida por Walsh (2008) como o posicionamento do eurocentrismo que toma como perspectiva única um conhecimento branco e europeu e desconsidera formas outras de conhecimento e de racionalidades epistêmicas.

Vitória traz uma força feminista, suas dores e lutas: "Sou a filha esquecida do mundo, minha cor é vermelha de dor!". Com ela, a colonialidade do ser, que se manifesta por meio da inferiorização e subalternização dos sujeitos e de suas capacidades cognitivas, desconsiderando sua existência por conta de sua cor ou de suas raízes, nos dizem Walsh (2008) e Fanon (2008).

De Janaína, uma mensagem afirmativa: “O meu canto é bravo e forte, mas é hino de paz e amor!". Ela nos aponta caminhos em que ecoa a pedagogia decolonial de Walsh (2008), "uma práxis baseada numa insurgência educativa propositiva - portanto, não somente denunciativa em que o termo insurgir representa a criação e a construção de novas condições sociais, políticas, culturais e de pensamento" (OLIVEIRA; CANDAU, 2010, p. 28). Assim, desafiar as estruturas e as instituições é parte do decolonial e da busca por pedagogias outras.

Sentimo-nos livres para criar esses quatro personagens e construir um diálogo ficcional entre as falas dos estudantes da escola básica e os povos autóctones, uma vez que "nosso objetivo na escrita de ficção é re-(a)presentar, apresentar novamente, momentos do processo para que possamos permanecer com eles, aprender sobre eles, apoiar-nos para a educação e a transformação" (LEGGO; SAMESHIMA, 2014, p. 542).

$\mathrm{Na}$ abordagem que adotamos, a presença dos autóctones aqui não se caracteriza como fonte de dados, nem como objeto de análise. Suas vozes dão materialidade a um fio condutor ficcional que se entrelaça com as vozes dos quatro personagens criados e que vêm da escola. $\mathrm{O}$ (res)soar dessas vozes em outro lugar de enunciação - deslocadas ao entrelugar onde nos encontramos -, reverberando no entrelaçamento entre falas de estudantes da escola e de autóctones e ecoando a partir de personagens fictícios colocados em diálogo, dá a essa narrativa um sentido de re-(a)presentação ficcional, como sugerem Leggo e Sameshima (2014).

A apresentação dos resultados dessa investigação não descreve uma análise de dados no sentido convencional da pesquisa educacional. Rompemos com o lugar usual de pesquisador, de forma que, do entrelugar onde estamos, dialoguemos com os estudantes da escola básica, com os pesquisadores e com as vozes autóctones. Nesse diálogo, procuramos não desqualificar as vozes dos estudantes ou dos autóctones, como se essas tivessem menos legitimidade que as dos pesquisadores com quem nos encontramos nesse entrelugar, tampouco as entendemos como 
objetivos de análise, sob a chancela da literatura de pesquisa. Procuramos, em vez disso, ouvilos juntos - estudantes, autóctones e pesquisadores - sobre que traços e efeitos da colonialidade e que formas de (re)existência seu coletivo revela. A partir do reconhecimento das dimensões macropolíticas e micropolíticas em que esses traços e efeitos se capilarizam, como denunciamos em Giraldo, Fernandes, Matos e Quintaneiro (2020), procuramos, nos diálogos com esses atores, percorrer entrelaçamentos entre tais dimensões.

O caminho que percorremos nos leva a uma forma de comunicação de resultados que hibridiza: uma exposição convencional, com uma análise sistemática de dados e conclusões encerradas pelos pesquisadores; e um formato narrativo, com considerações transitórias, que liberam o leitor a construir suas próprias interpretações em uma história (re)contada e (re)criada pelos autores (CRESWELL, 2007; BARBOSA, 2015). Ao nos posicionarmos nesse entrelugar metodológico, expomos os dilemas vivenciados em nossos fazeres de pesquisa que, mesmo tentando resistir e se insubordinar, ainda refletem e se submetem a uma ordem acadêmica convencional - reverberando uma tensão que impele a decolonizar também as metodologias.

Nesse formato híbrido, utilizamos a análise do discurso por considerarmos que o discurso dos estudantes da escola básica pode encobrir assujeitamentos de outros discursos que determinam o que (não) pode e (não) deve ser dito por sujeitos que não são a fonte de seu dizer, mas têm a ilusão de sê-lo (PÊCHEUX, 2006; ORLANDI, 2009). Nosso papel ao interpretar esses discursos, portanto, não é revelar uma verdade oculta atrás do texto, mas problematizar o que o texto, possivelmente, apaga. Com esse intuito, nos apropriamos de recursos como paráfrases e metáforas para produzir formações discursivas que possibilitem deslocar o sentido dos discursos a lugares que problematizem seus não-ditos.

No lugar onde estamos, o silêncio pode ser ouvido, o não-dito pode dizer, o apagado pode ser visto, a insensibilidade pode ser sentida... Alex, Davi, Vitória, Janaína, Cacique Raoni, autóctones do Xingu e das etnias Xavante e Mehinaku nos convidam a ouvir, dizer, ver e sentir seus gritos por liberdade.

\section{3 "Sou guerreiro imortal derradeiro, deste chão o senhor verdadeiro!"}

Alex: O método educacional presente e efetuado há muito tempo, há mais de um século, é o mesmo que ainda utilizamos: "decorar matérias". Disfarçando-se de muitos outros verbos e passando despercebido perante as gerações. Esse método não é, porém, muito questionado. É aceito, usado e persuasivo a ponto de pensarmos que não há outras propostas. E oficiais não há mesmo. O sistema educacional usado aqui no Brasil é o mesmo e assim imutável. A educação não é valorizada, muito por quem a usa e, também, por quem não conseguiu utilizá-la.

(Trecho das redações dos alunos da escola básica, 2017-2018). 
Suas palavras, Alex, refletem um projeto de poder mais amplo, que oculta lutas de resistência de modo tão "persuasivo a ponto de pensarmos não haver outras propostas". Quijano (2000) chama esse projeto de colonialidade do poder, que tem como base um sistema hierárquico de classificação social, de saberes e visões de mundo, personificado na figura do homem branco europeu. As políticas públicas de educação são estruturantes para esse projeto de poder. Nesse sentido, as "propostas oficiais" ditam não só o ritmo das mudanças nas estruturas educacionais, mas, sobretudo, a falta de mudanças que determina sua inércia, fazendo com que tal sistema hierárquico pareça e permaneça "imutável". Parafraseando ${ }^{8}$ você, Alex, "o método educacional, (com suas políticas públicas e propostas oficiais), é aceito, usado e persuasivo a ponto de (nos fazer pensar) que não há outras propostas".

Ao afirmar que "o método educacional presente, há mais de um século, é o mesmo que ainda utilizamos: decorar matérias", Alex nos remete a um passado não tão recente, evidenciando que o projeto de poder ao qual nos referimos atravessa a história de nosso país. Pouco depois do "descobrimento" do Brasil, os autóctones que aqui habitavam foram catequizados pelos jesuítas portugueses, como meio de fortalecimento da cultura europeia e de descaracterização da cultura autóctone. "O método educacional presente (na catequização dos autóctones durante o período colonial), há mais de um século, é o mesmo que ainda utilizamos: decorar matérias (que desconsideram sua cultura e sua forma de pensar)".

Esboçamos essa analogia entre os sistemas educacionais passado/presente para ressaltar que, como aponta Maldonado-Torres (2007), a colonialidade se refere a um padrão de poder que emergiu do colonialismo e sobrevive a ele. Quijano (2000) situa a origem da colonialidade do poder em debates, durante o período de colonização na América Latina, sobre se os autóctones teriam alma. No contexto da colonização europeia, classificações como branco, índio, negro, mestiço nomeavam uma relação vertical entre corpos. Maldonado-Torres (2007) nos diz, ainda, que tudo isso serviu à criação de novos mapas do mundo, sob o ponto de vista dos colonizadores, configurando uma geografia rasgada à luz de uma lógica capitalista-global constituída com base na figura do homem branco europeu. A história evidencia que, onde hoje se chama Brasil, não foi (e ainda não é) diferente. Os autóctones presentes, hoje e aqui, podem nos falar mais sobre isso.

Autóctones: Nossos antepassados, nossos avós aceitavam os "presentes" que vocês deixavam para enfeitiçar nosso povo e pensavam que era uma atitude de amizade verdadeira. Acreditavam que aceitando os presentes vocês iam nos respeitar, que estaríamos protegidos. Mas, essa história se repete. As frentes de atração continuam usando essa mesma tática para

\footnotetext{
${ }^{8}$ Nesta seção e nas seguintes, quando utilizarmos o recurso da paráfrase em formações discursivas que visam a evidenciar as condições de produção do discurso, destacaremos, em itálico e entre parênteses, os termos que deslocam o sentido dos trechos originais citados entre aspas.
} 
atrair e iludir nossos parentes que nem sabem que o Brasil existe. Vivemos neste lugar há muito tempo, muito antes dele se chamar Brasil. Nossos ancestrais andavam aqui em liberdade... Hoje vivemos cercados, em pequenos pedaços de terra. Para todo lado que andamos existem sinais daquilo que vocês chamam progresso.

(Autóctones das etnias Xavante e Mehinaku, 2000).

Vocês, autóctones que aqui estão junto com Alex, nos revelam que a lógica subjacente à colonialidade do poder permanece presente hoje em nome do "progresso". Walsh (2009) nos alerta que tanto o sistema legal como o educacional têm servido como dispositivos de regulação, legitimando a subordinação à moderna ordem colonial. Essa subordinação pode levar à aceitação sem questionamento ou, ainda, atuar de forma silenciosa "disfarçando-se de muitos outros verbos e passando despercebido perante as gerações”, como Alex mesmo nos disse. Quais seriam esses "outros verbos” que Alex não menciona? Verbos que disfarçam outros que são apagados, verbos silenciosos e que nos silenciam, verbos não-ditos, mas que dizem por nós. Não por acaso, Walsh (2009) utiliza quatro verbos entrelaçados para descrever esse projeto de poder: evangelizar-civilizar-governar-educar, que visam a consolidar uma sociedade, supostamente, homogênea, monocultural, cordial e, consequentemente, excludente e violenta.

Os verbos apagados em sua fala, Alex, podem ser relacionados àqueles que sustentam o projeto de poder descrito por Walsh (2009). Ao estabelecermos um diálogo entre suas palavras e a fala dos autóctones aqui presentes, podemos entender que a exclusão pode passar despercebida e ser naturalizada por quem está nas periferias desse sistema hierárquico. " $A$ educação não é valorizada por quem a usa e, também, por quem não conseguiu utilizá-la. As frentes de atração continuam usando essa mesma tática para atrair e iludir nossos parentes que nem sabem que o Brasil existe". Neste intertexto, os autóctones falam junto com Alex, trazendo à tona a possibilidade de que grupos subalternizados ou esquecidos pelo sistema educacional não tenham sequer ciência de que estão presentes em um Brasil onde a educação pública de qualidade deveria ser um direito de todos. Ao "aceitarem os 'presentes' deixados para enfeitiçar nosso povo e pensarem que se trata de uma atitude de amizade verdadeira”, esses corpos excluídos podem ser "iludidos" a não valorizarem a educação e serem "atraídos" a uma posição social que os exclui de uma nação que podem nem saber que existe.

Reconhecemos que a matemática pode estar a serviço dessa exclusão. Bishop (1999) denuncia um processo de enculturação na escola básica, no qual professores e estudantes moldam, em sua interação, os valores que cada estudante receberá em sua relação com a matemática, sem perder de vista, entretanto, as limitações estabelecidas pela sociedade, as influências institucionais e os próprios valores culturais que a matemática carrega. Exatamente 
nesse ponto, abre-se um caminho para a utilização da matemática como mecanismo de regulação e de exclusão, no campo da educação, a serviço da colonialidade.

Alex: Matemática é uma matéria superestimada, conhecida como o terror e uma das "piores" matérias e mais dificeis. Para mim, a matemática quer que você seja um "gênio" porque, se você não for, seu futuro não está totalmente garantido. Nossa preocupação, que não advém de uma vontade cultivada por nós, é passar de ano. Achar formas efetivas e rápidas de gravar conhecimento sem entendê-lo, sem entender a necessidade de aprender o que os professores escrevem no quadro. É só sobre passar de ano. E, agora, é só sobre passar no vestibular e seguir o cronograma de "vida normal e sucedida" determinada por outras forças, que consentimos, por vezes, não questionamos e, esmagadoramente, não queremos.

(Trecho das redações dos alunos da escola básica, 2017-2018).

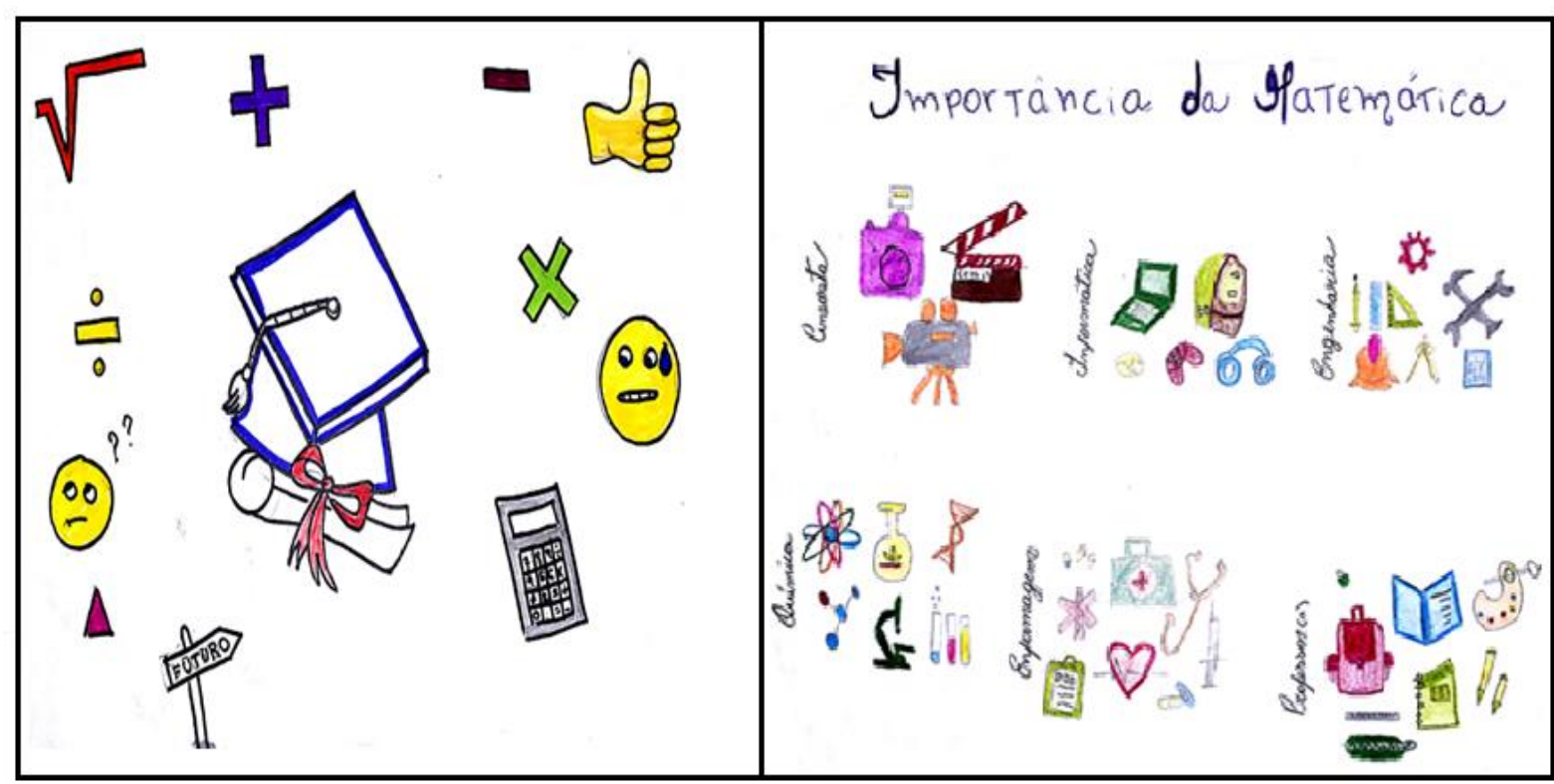

Figura 1 - Matemática(s) como passaporte para um futuro promissor Fonte: Dados da pesquisa (2019)

A que forças você se refere, Alex? Quem determina qual é o cronograma de vida normal e sucedida? Talvez seu desenho nos dê uma pista. Nele, a placa que mostra o caminho para o futuro aponta na direção de um diploma, cujo objetivo final é o exercício de uma profissão. Reconhecida pela sociedade como instituição produtora de conhecimento, "hoje a uni-versidade funciona como empresa científica, profissionalizante e desumanizante com cumplicidade direta com o poder do capital" (WALSH, 2017, p. 36, tradução nossa). Assim, a supervalorização da matemática parece estar a serviço de uma lógica capitalista-global, vista pelos estudantes como determinante para conseguir um emprego que possibilite um "futuro de sucesso".

Como você bem disse, Alex, essa "vida normal e sucedida" é "determinada por outras forças" - a colonialidade do poder - que tentam impor matemática(s) às quais vocês resistem "esmagadoramente, não queremos". Sua fala e seu desenho resumem o que discutimos aqui e nos mostram que seu grito por liberdade denuncia a manifestação da colonialidade do poder no ensino de matemática(s) nas escolas. Compreendemos sua mensagem, Alex. A partir de agora, 
“consentir", "não questionar" e aceitar, passivamente, a colonialidade do poder não fazem parte de nossa resistência e dos caminhos propositivos que buscamos no lugar onde nos encontramos.

\section{4 "O belo monstro rouba a terra dos seus filhos!"}

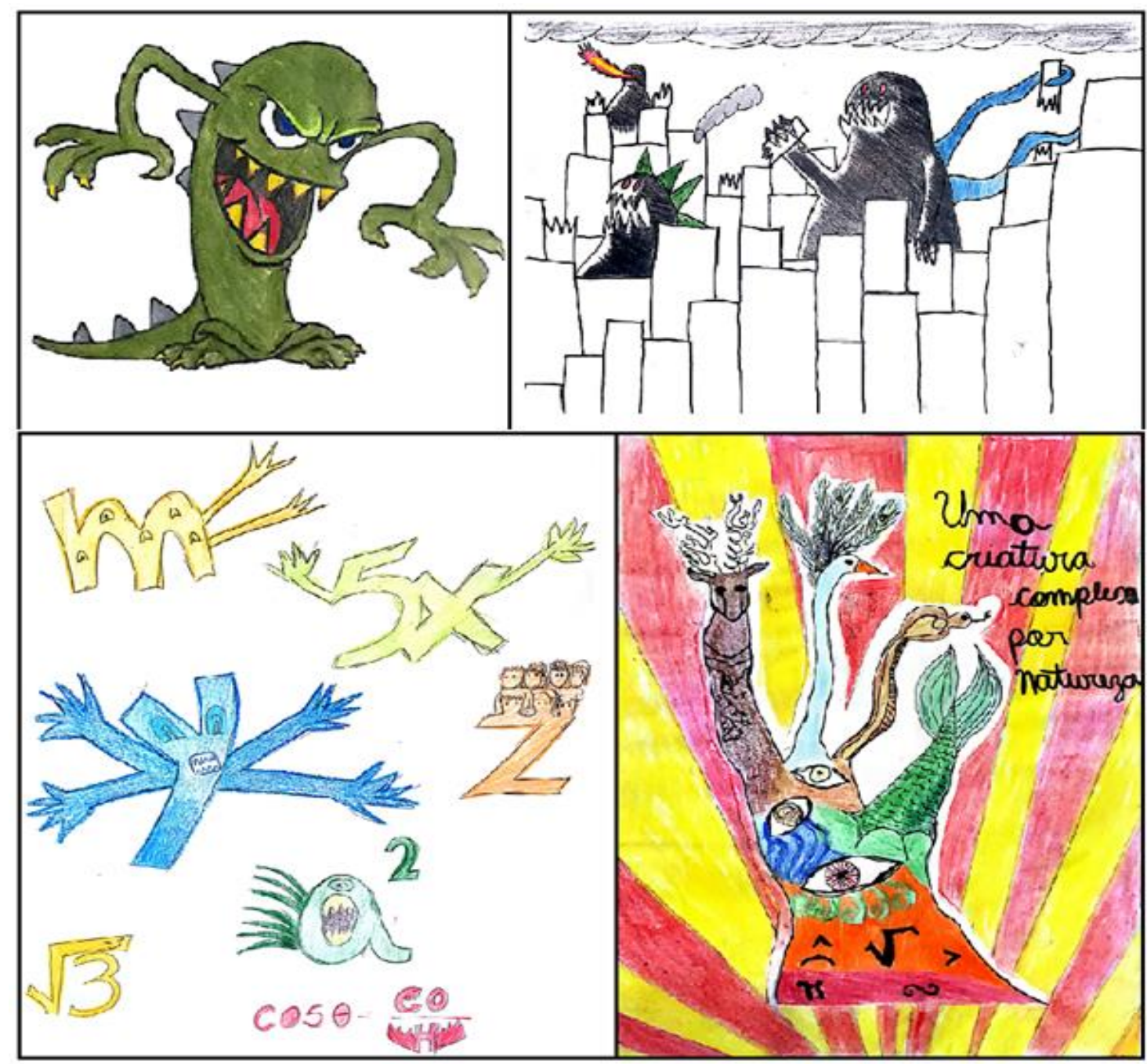

Figura 2 - Belos monstros

Fonte: Dados da pesquisa (2019)

Davi: Matemática, para a grande maioria, é um grande monstro. Muitos amigos meus encaram a matemática como um monstro, tipo aqueles que ficam embaixo da cama quando você é pequeno. Foi criado um estereótipo em cima da matemática onde esse monstro é impossível de ser vencido. As pessoas têm medo da matemática, desse grande monstro que poucos entendem, que pode fazer com que você tenha que refazer um ano inteiro, quem sabe dois... Esse medo que eu e muitos alunos temos em relação à matemática vem do sistema de ensino que nos é apresentado, em que matemática é uma das matérias mais importantes. Se não formos bons, não conseguiremos um bom futuro. Isso é algo que deveria ser desconstruído com a ajuda de uma nova dinâmica que vai além da sala de aula.

(Trecho das redações dos alunos da escola básica, 2017-2018, grifo nosso). 
Autóctones: Caraíba 9 não mede consequências. Acredita na sua ciência, buscando o que chama de progresso. Derruba floresta, espalha veneno e acha o mundo pequeno para semear tanta arrogância. Invade nossas terras, liga a motosserra e no lugar dos troncos sagrados, planta ganância. Caraíba precisa de mais energia para alimentar os seus interesses. Cria verdadeiros monstros. Belos monstros ... usinas que devoram rios, matam peixes, secam nascentes, inundam tabas e arrastam na lama o futuro de nossa gente. Não podemos deixar, guerreiro menino, que afoguem o nosso destino. Nossa casa é aqui! E não devemos nos curvar. Precisamos honrar cada dente do colar, cada palavra do irmão Raoni ${ }^{10}$ !

(Autóctones do Xingu, sinopse do enredo da G.R.E.S. Imperatriz Leopoldinense, 2017, grifo nosso)

Não nos curvaremos! Lutaremos juntos contra esses monstros, belos monstros... Monstros cuja beleza parece estar encoberta pelas imagens que nos são apresentadas. Essa imagem das matemática(s), apresentadas na escola como monstros, precisa ser desnaturalizada. Seu grito por liberdade, Davi, nos apresenta a colonialidade do saber: "o posicionamento do eurocentrismo como a perspectiva única de conhecimento, a que descarta a existência e viabilidade de outras racionalidades epistêmicas e outros conhecimentos que não sejam os dos homens brancos europeus ou europeizados" (WALSH, 2008, p. 137, tradução nossa). Walsh (2008) ressalta que a colonialidade do saber está enraizada no sistema educativo, da escola até a universidade, onde essa perspectiva única de conhecimento é elevada e legitimada como marco científico-acadêmico-intelectual.

A metáfora ilustrada em seu desenho, Davi, que relaciona as matemática(s) a monstros, personifica o "estereótipo criado em cima da matemática como monstro impossível de ser vencido". Tamayo-Osorio (2017) nos conta que essa imagem é fruto de uma dieta unilateral que alimenta uma única visão de matemática, apresentada como exata, precisa, verdadeira, sem espaço para o erro. Tal imagem reforça a legitimação, na escola, das matemática(s) como marco científico-acadêmico-intelectual, evidenciando a manifestação da colonialidade do saber a partir do "medo que muitos alunos têm em relação aos (monstros) da $(s)$ matemática $(s)$ (criados pelo) sistema de ensino que é apresentado, em que matemática(s) é uma das matérias mais importantes". A partir do momento em que Davi se refere às matemática(s) como uma das matérias mais importantes, sua fala aponta para a exclusão oculta de outras epistemologias na escola, concebidas como conhecimentos menos importantes. Assim, Davi, questionamos: quais outras epistemologias consideradas menos importantes teriam sido apagadas em sua fala?

Davi: Não tenho uma concepção exata do que é matemática. Sei que ajuda a trabalhar a lógica e que a maioria das pessoas te considera inteligente se você a compreende. O que realmente me intriga não é a matemática em si, e sim a importância dada a ela. Por que entender matérias

\footnotetext{
${ }^{9} \mathrm{O}$ termo caraíba é usado por algumas etnias autóctones para se referir ao homem europeu ou branco.

${ }^{10}$ Raoni é um cacique da etnia Kayapó, reconhecido por sua luta pela preservação da floresta e em defesa das culturas e dos povos autóctones, lutando, por exemplo, contra a construção da Usina Hidrelétrica de Belo Monte na bacia do Rio Xingu.
} 
tão importantes como Sociologia e Filosofia não te dá um "status"? Não desvalorizo sua importância, mas por que outras matérias como Filosofia, Sociologia e Artes não tem a mesma importância que ela? Matemática foi sempre apresentada para mim como algo muito importante, que os mais inteligentes dominam e tem facilidades com equações, etc. Mesmo eu não achando isso, a sociedade, as pessoas, as escolas reforçam tanto essa ideia de que, quando tiramos uma nota ruim nessa matéria, ou nos sentimos um lixo, ou ficamos nem ai para a nota, porque sabemos que só os mais inteligentes a dominam.

(Trecho das redações dos alunos da escola básica, 2017-2018).

Davi, esse "status" de superioridade que as matemática(s) carregam emerge da colonialidade do saber, que, segundo Walsh (2009), construiu um lugar hegemônico de onde é possível controlar o conhecimento sobre o mundo, a partir de seu entendimento sobre o que é ciência. As ciências ditas "naturais" ocupavam seu lugar como ciência do mundo real, objetivo. Walsh (2009) conclui, então, que as ciências "humanas" foram relegadas a uma condição inferior, como matérias não empíricas e com conhecimento efêmero.

Davi nos descreve uma hierarquia de saberes, na escola, que situa as Ciências Humanas e as Artes em um patamar inferior, ao questionar, por exemplo, por que "outras matérias como Filosofia, Sociologia e Artes não tem a mesma importância que a Matemática e não te dão um status”. A legitimidade do conhecimento matemático não está em discussão na fala de Davi, mas sim o apagamento de outras formas de saber que, na escola, são rotuladas como "menos importantes".

O sentimento de Davi revela que a colonialidade do saber demarca socialmente as fronteiras do conhecimento: "mesmo eu não achando isso, a sociedade, as pessoas, as escolas reforçam tanto essa (hierarquia de saberes)". O diálogo com Walsh (2009) nos mostra o poder da educação como projeto de governo que normatiza essa concepção de conhecimento e que regula quem está no interior de suas fronteiras. Tais mecanismos de regulação acabam por determinar os discursos daqueles que são subalternizados por esse conhecimento de referência: "quando tiramos uma nota ruim (em matemática(s)), ou nos sentimos um lixo (por não alcançar o status que almejamos nessa hierarquia de saberes), ou ficamos nem aí para a nota, porque sabemos que só os mais inteligentes a dominam (e podem ocupar tal lugar)".

Diante disso, Davi, nos perguntamos, agora, a quem interessa essa imagem das matemática(s) como belos monstros? Para Wash (2009), podemos ir mais além do currículo e das políticas educacionais e denunciar que "a educação contribuiu - e segue contribuindo - para a colonização das mentes, para as noções de 'singularidade', 'objetividade' e 'neutralidade' da ciência, do conhecimento e da epistemologia, e de que algumas pessoas são mais 'aptas' a pensar do que outras" (WALSH, 2009, p. 186, tradução nossa).

Davi: Estudar matérias de exatas para mim é estressante, pois nelas se alcança o conhecimento através da repetição. Não é como História ou Filosofia que eu entendo o que leio e melhoro 
através do debate. Muita gente decora a fórmula de Bhaskara, mas chega na prova e a maioria não sabe aplicar. É uma matéria muito rígida na maioria das vezes. Sem reflexão. Eu sei muito bem que essas operações e contas são muito importantes, mas não consigo visualizar onde elas podem ser aplicadas porque em todas as provas, livros e aulas nos jogam exercícios com situações irreais. Sinceramente, não sei de onde os meus professores tiraram que usamos a matemática em tudo. De coração, eu só uso a matemática mesmo para contar os trocos, não fico olhando uma placa na rua tentando achar a área de um polígono regular. Eu não vou olhar para um prédio, uma rampa, e pensar qual será o seno, o cosseno e a tangente do ângulo tal. Eu simplesmente continuarei andando e ignorarei a rampa.

(Trecho das redações dos alunos da escola básica, 2017-2018).

$\mathrm{Na}$ hierarquia de saberes estabelecida pela colonialidade do saber, "provas, livros e aulas nos jogam exercícios com situações irreais (em uma exposição que busca naturalizar, entre estudantes e professores, que) usamos a $(s)$ matemática( $(s)$ em tudo". Por um lado, a idealização do conhecimento matemático como algo "que está em tudo" confina a disciplina a uma matemática utilitária, que "(restringe o sentido) da $(s)$ matemática $(s)$ (somente) a contar os trocos, (enquanto desvia nosso olhar para) uma placa na rua tentando achar a área de um polígono regular, para um prédio, para uma rampa, e pensar qual será o seno, o cosseno e a tangente do ângulo tal”. Por outro lado, essa idealização naturaliza a matemática como um sentido privilegiado, intrínseco ao mundo, e invisibiliza outras opções políticas sobre que sentidos se quer dar ao mundo. Sobre isso, Davi, suas palavras ecoam com as de outros autores:

\footnotetext{
Os sentidos que esses lemas podem produzir não estão apenas em suas implicações lógicas, mas sobretudo em seus não ditos. [...] Se a matemática "está em tudo", então não estão igualmente em tudo a história, a filosofia ou as artes populares? E que "tudo" é esse? Que lugares são legitimados dentro desse "tudo", e que sabedorias e que corpos são excluídos, ficam de fora desse "tudo"? (GIRALDO et al., 2020, grifo no original).
}

Devemos, portanto, enfrentar a colonialidade do saber e desnatu

ralizar essa exposição das matemática(s), que cria os belos monstros apresentados por Davi. Belos monstros não nos assustarão mais, Davi. Seu grito por liberdade tem força e alimentará a esperança de vencê-los!

\section{5 "Sou a filha esquecida do mundo, minha cor é vermelha de dor!"}

Autóctones: Estamos aqui com nossa verdade e isso dói. Traz dúvidas e dor. Porque não sabemos se vocês vão ser capazes de enxergar o que estamos trazendo.

(Autóctones das etnias Xavante e Mehinaku, 2000).

Não podemos sentir a dor de vocês, mas podemos sentir a verdade que seu povo traz. Os gritos por liberdade de Alex e Davi, junto com todo o histórico de luta e resistência dos povos autóctones, nos alertaram sobre a colonialidade do poder e do saber, nos mostrando ser necessário que a verdade seja dita, mesmo que traga “dúvidas e dor". Por sinal, é preciso tocar 
também nessa ferida, conhecer suas angústias, seus lamentos, suas dores. Talvez, aquela menina ali possa nos ajudar. Vemos, em seus olhos, que ela parece sentir a dor que descrevestes. Vitória é seu nome e daqui consigo ouvir seu grito por liberdade: "Sou a filha esquecida do mundo, minha cor é vermelha de dor!".

Vitória: Sinceramente, matemática só serve para me dar dor de cabeça, problemas psicológicos e gastar dinheiro com remédio e explicador. $O$ modo como a matemática é supervalorizada é um problema muito grande, pois quando você é bom, está tudo "de boa", mas quando você não $e ́$, isso se torna um problema. Os problemas aparecem, as cobranças e junto o desespero. Desde pequena eu tinha problema com a matemática e, por conta disso e da minha grande falta de atenção, comecei a frequentar o psiquiatra para tomar vários remédios que acabavam comigo tanto psicologicamente, quanto fisicamente. Está muito acoplado em nossas cabecinhas, desde o começo de nossa trajetória escolar, por frases mal planejadas, por falta de reflexão de como elas nos afetariam ou, por vezes, mal intencionadas de professores que sabiam que isso nos amedrontaria, a ideia de que não somos capazes suficientes para entender matemática.

(Trecho das redações dos alunos da escola básica, 2017-2018, grifo da autora).

Compartilharmos nossas angústias e dividirmos nossas dores é uma maneira de resistirmos, Vitória. Sua manifestação de resistência revela efeitos da colonialidade e seu impacto sobre o ser. Seu desabafo, portanto, nos apresenta a colonialidade do ser, que se refere à experiência vivida da colonialidade, exercida por meio da inferiorização e subalternização do indivíduo (MALDONADO-TORRES, 2007; WALSH, 2008), descrita por Fanon (2008) como o tratamento da "não-existência". Walsh (2013) ressalta que a colonialidade do ser nos remete à dimensão ontológica da colonialidade. Para a autora, "o ser é entendido não mais como uma entidade universal e neutra, mas como uma categoria ontológica concreta que, a partir do pensamento ocidental e da conquista, impõe a superioridade e diferenciação de alguns seres sobre outros" (WALSH, 2013, p. 99, tradução nossa).

Vitória, permita-nos reconstruir o final de sua fala para ilustrar o que Walsh (2013) diz. O uso do ser como meio para implementar o projeto colonial (colonialidade do poder) configura um cenário propício, na escola, para "(fomentar em alguns indivíduos) a ideia de que não somos capazes suficientes para entender matemática(s), (sendo acoplada em nossas cabecinhas), desde o começo de nossa trajetória escolar, através de frases mal planejadas (que são interiorizadas e naturalizadas) por falta de reflexão de como elas nos afetariam”. Como nos dizem Oliveira e Candau (2010), esse discurso se insere no mundo do colonizado, invade e destrói seu imaginário, inviabilizando-o e subalternizando-o ao mesmo tempo em que o colonizador reafirma seu próprio imaginário.

Situando a fala de Vitória na perspectiva de Oliveira e Candau (2010), notamos que não somente o impacto sobre o ser é narrado na primeira pessoa, mas, também, suas causas, reforçando no imaginário de Vitória uma coautoria dos problemas que ela vivencia. Em seu 
imaginário como indivíduo subalternizado, constrói-se uma subjetividade que afirma: "Desde pequena eu tinha problema com a matemática e, por conta disso e da minha grande falta de atenção, comecei a frequentar o psiquiatra para tomar vários remédios que acabavam comigo tanto psicologicamente, quanto fisicamente”. Em contrapartida, produzimos outra narrativa possível, na qual o colonizador reafirma seu próprio imaginário: "Desde pequena (diziam que eu tinha problema com as matemáticas) e, por conta disso e (por me acharem desatenta, me recomendaram) frequentar o psiquiatra para tomar vários remédios que (cuidariam de mim) tanto psicologicamente, quanto fisicamente". Essa narrativa sugere a construção de uma subjetividade que subalterniza o próprio indivíduo como ser, ao convencê-lo de que não é capaz de aprender matemática(s) e desqualificar suas capacidades.

Vitória: Enquanto eu escrevia esse texto, ouvi uma das palavras utilizadas para descrever a matemática: inferno. "Lugar onde as almas pecadoras se encontram após a morte, submetidas a penas eternas", de acordo com o Google. Não seria isso errado? Me deixa triste ver algo que considero importante com a imagem tão manchada. Mas, honestamente, não acho que seja culpa da matemática, nem do(a) professor(a) x ou y, e sim de todo um sistema educacional que prioriza notas em relação a tudo, principalmente à saúde mental. Se não fosse transmitida tanta pressão, se existissem métodos de avaliação que ultrapassassem as provas que nos deixam muito, muito ansiosos, que levam a gente a esquecer o conhecimento memorizado, até nos provocam verdadeiras crises de ansiedade e ataques de pânico que nos agridem profundamente e deixam marcas fixas de que nunca seremos capazes, teríamos mais matemáticos e amantes, singelos amantes, da área de exatas. Menos pressão em uma prova, mais ensino, mais argumentação. E todos os alunos respirariam de forma límpida e despida de inquietações que nos afastam de tudo que poderíamos ser.

(Trecho das redações dos alunos da escola básica, 2017-2018). 


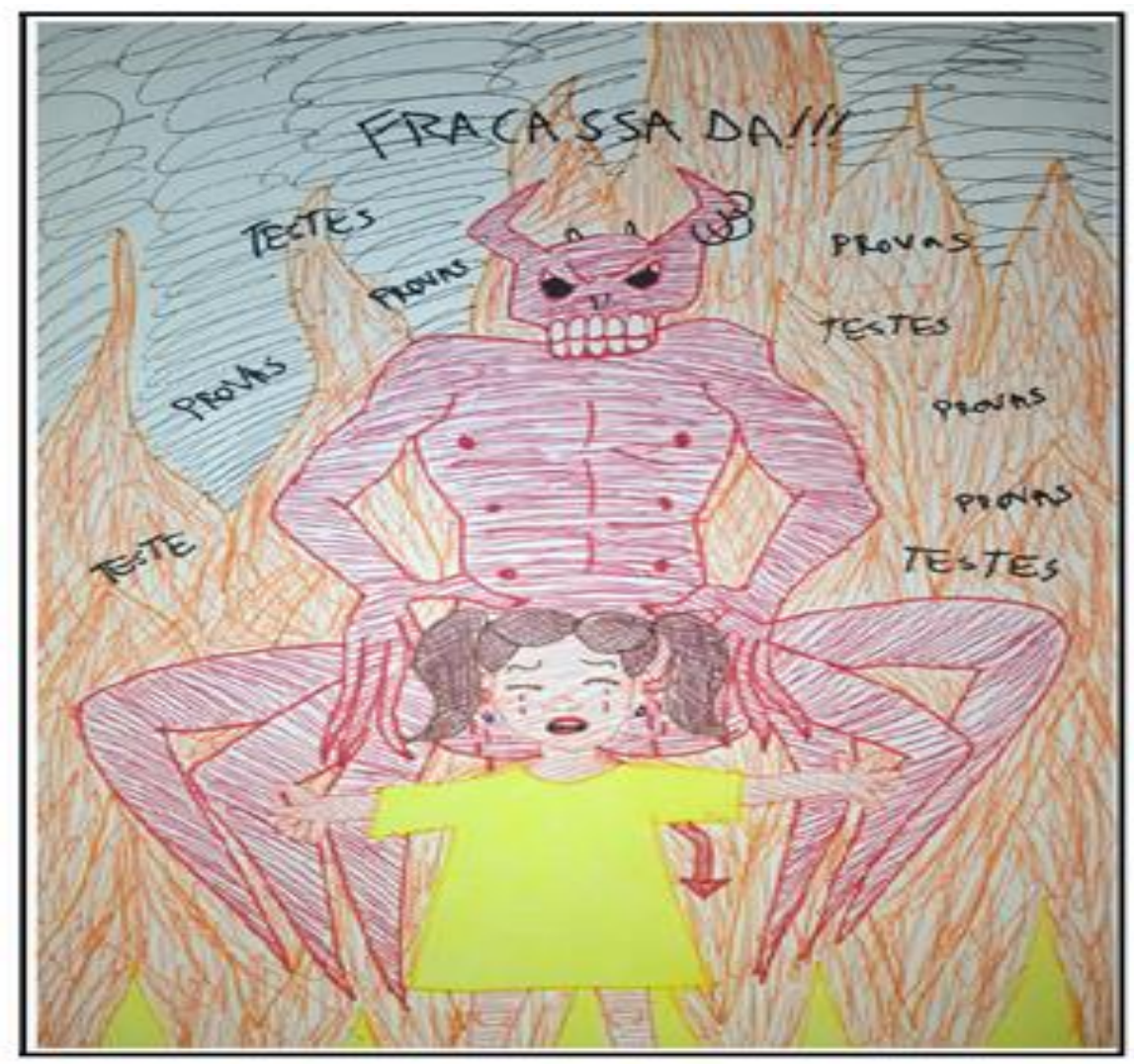

Figura 3 - A subalternização do indivíduo

Fonte: Dados da pesquisa (2019)

De fato, Vitória, não se trata de culpar professores individualmente. A discussão é mais ampla e envolve "todo um sistema educacional", como você disse. "Não é que o professor não reconheça a humanidade e os interesses pessoais dos estudantes como indivíduos: é o ensino de matemática que não os reconhece" (BISHOP, 1999, p. 30). O diálogo com Bishop (1999) nos mostra que o ensino de matemática tem sido marcado por uma aprendizagem impessoal, caracterizada por uma concepção que desconsidera a individualidade do estudante, como se o ensino de matemática ocorresse independente - ou apesar - de sua pessoa.

Sua metáfora com o inferno situa as matemática(s) não apenas como um lugar de sofrimento, mas como um lugar de julgamento. Com seu desenho, metaforicamente comparamos testes e provas ao juízo final, que ocorre sob a sombra de um "sistema educacional que prioriza notas" e "transmite tanta pressão" ao situar as matemática(s) como "lugar onde as almas (fracassadas) se encontram após (notas baixas), submetidas a penas eternas (decorrentes da reprovação em um ano letivo)". A construção de subjetividades no interior desse discurso e seu impacto sobre o ser são evidenciados quando Vitória nos diz que tudo isso "nos agride profundamente e deixa marcas fixas de que nunca seremos capazes", nos rotulando como indivíduos subalternizados em um lugar que "nos afasta de tudo que poderíamos ser". 
Vitória: Não gosto de matemática, da área de exatas em geral, e muito disso vem porque é uma área dominada pelo masculino. Tendo a mesma nota que um colega menino, ele é um gênio, potencial engenheiro, eu só ganho um parabéns por passar de ano. Eu, para estar na mesma posição que ele, tenho que me provar ser duas vezes melhor, não tenho margem para errar, enquanto ele é um menino e, portanto, não o questione. Historicamente dominada pelo masculino, não seria diferente na escola. Inúmeras vezes não recebi o mesmo tratamento dos professores que os meus colegas do sexo masculino. Admiro muito as "minas" que persistem na área de exatas e querem isso em sua vida profissional. Só estou cansada, mas vou continuar estudando para isso durante a escola enquanto sou obrigada.

(Trecho das redações dos alunos da escola básica, 2017-2018).

Discutimos, na seção anterior, como a colonialidade do saber evidencia que a história do conhecimento tem "valor, cor e lugar de origem". Seu depoimento, Vitória, nos mostra, agora, que é preciso sublinhar o termo gênero nessa classificação. Como reforça Löwy (2009), é importante demarcar que as noções de neutralidade, objetividade, racionalidade e universalidade da ciência foram construídas histórica e culturalmente a partir da figura do homem branco europeu e, portanto, incorporam a visão de mundo de uma identidade social específica, moldada por uma dicotomia entre masculino e feminino. A pesquisadora acrescenta que a história da ciência - em particular, atentamos para as matemática(s) - é apresentada como uma sucessão de obras de figuras masculinas, com o acréscimo de "descobertas" importantes de algumas mulheres escolhidas. Diante do apagamento de personagens femininos nas matemática(s) e da falta de identificação com as figuras masculinas apresentadas, as estudantes vivenciam a subalternização de suas identidades com a manifestação da colonialidade do ser, "tendo que provarem ser duas vezes melhor que seus colegas do sexo masculino para conquistarem a mesma posição que eles e receberem o mesmo tratamento de seus professores".

Devemos romper com a binarização de gênero e com a subordinação do feminino ao masculino, como tantas outras dicotomias que nos isolam (mente/corpo, humano/natureza). Devemos nos inspirar na concepção de natureza dos povos autóctones, entendida não como "recursos naturais", mas como espaço muito mais amplo, onde os corpos são parte da própria vida em si, onde a divisão entre homem e mulher não tem sentido como seres individuais, somente como parte de um coletivo (WALSH, 2013). Compreendendo a vida dessa maneira, o grito por liberdade de Vitória não permitirá que se tornem "filhas esquecidas do mundo".

\section{6 "O meu canto é bravo e forte, mas é hino de paz e amor!"}

Autóctones: Respiramos todos um só ar, bebemos todos a mesma água, vivemos todos em uma só terra. Nós devemos protegê-la. Precisamos proteger a cultura de nossos antepassados, em 
conexão direta com a natureza. Uma luta pela vida ${ }^{11}$.

(Cacique Raoni, etnia Kayapó).

Essa conexão com a natureza nos faz compreender que, mais do que transmitir uma mensagem positiva, é preciso incorporar suas palavras na própria vida em si, como uma atitude, como uma postura, como parte de nossa existência. Durante nossa experiência neste lugar, conseguimos perceber que os gritos por liberdade proclamados aqui por Alex, Davi e Vitória não representam somente expressões de susto, de espanto, mas, principalmente, ações de luta, resistência, insurgência, ruptura e transgressão diante das tentativas de silenciá-los, representando, portanto, uma prática e uma intervenção que apontam para uma atitude decolonial (WALSH, 2017; MALDONADO-TORRES, 2007).

A utilização do termo decolonialidade, ao invés de "descolonialidade", por Walsh (2013), marca uma posição política de que não é possível passar de um estado colonial para um não-colonial, como se existisse um estado nulo de colonialidade, livre de seus traços e efeitos. Para a autora, o decolonial se refere a um caminho de luta em busca de construções "alter(n)ativas" (termo usado pela autora, ibid., p. 25). Walsh (2017) nos desafia a desaprender a pensar da perspectiva hegemônica e a atuar em seus arredores, em suas fissuras, em suas rachaduras. "Nas rachaduras é onde começa a se entrelaçar e semear, sem dúvida, processos, práticas e possibilidades do intercultural e do decolonial, não como substantivos fixos, mas como 'verbalidades' que despertam o seu agir ativo, a sua ação" (WALSH, 2017, p. 44, tradução nossa). Esse deve ser nosso lugar a partir de agora, Janaína, atuando nessas rachaduras e buscando ampliá-las com nossa luta e resistência.

Janaína: Falta dar voz aos alunos e alunas, falta sensibilidade e percepção. O mundo está se modernizando e o método de ensino não. O que é novo instiga, gera curiosidade e nos faz aprender. Não é porque matemática está na categoria de "exatas" que não podemos explorála de outro jeito, com trabalhos dinâmicos. Não é sobre como é "certo" ensinar, é sobre como os alunos absorvem todas essas informações. É preciso incentivo, é preciso dizer com todas as letras: "VOCÊ É CAPAZ DE ENTENDER! VOCÊ É CAPAZ!", pois muitas vezes nós próprios não acreditamos e não reconhecemos nosso potencial.

(Trecho das redações dos alunos da escola básica, 2017-2018, grifo da autora).

Muito prazer, Janaína. Faltava seu grito por liberdade para nos encher de esperança: “ $O$ meu canto é bravo e forte, mas é hino de paz e amor!". Você é capaz de levar essa mensagem adiante. É preciso gritar, mesmo, para romper a ação do silenciamento que atua não apenas como substantivo, mas como verbo. Ao silenciarem - como verbo - alunos e alunas nas escolas, você é levada a crer que "falta dar voz aos alunos e alunas", como se ecoar sua voz fosse uma concessão daqueles que detêm a palavra. Na verdade, "falta (ouvir) os alunos e alunas".

${ }^{11}$ Disponível em: 〈http://raoni.com/palavras.php >. Acesso em 24 de fevereiro de 2020. 
Referimo-nos a deixar de pensar em nossas ações a partir da totalidade do silêncio - aqui, como substantivo - que, em seu vazio, acaba determinando grupos subalternizados que aguardam ávidos para ouvirem em suas escolas: “Você é capaz de entender! Você é capaz!”. Devemos subverter as palavras enunciadas, deixando de lado o que esperamos ouvir, em direção ao que queremos gritar: nós que afirmamos que somos capazes. Portanto, Janaína, grite "com todas as letras" que "nós próprios (acreditamos) e (reconhecemos) nosso potencial" e, por isso, "EU SOU CAPAZ DE ENTENDER! EU SOU CAPAZ!”.

Interpretamos esse vazio do silêncio como um lugar de possibilidades, como uma fissura, na perspectiva decolonial de Walsh (2017), caminhando para a proposição de pedagogias outras que problematizem e provoquem deslocamentos nas instituições e em suas estruturas. Não nos referimos, apenas, a pedagogias no sentido instrumentalista do ensino, muito menos de sua redução à escola e à educação. Walsh (2008) propõe um entendimento de pedagogias como caminhos para interpretar o mundo de forma crítica e intervir na reinvenção da sociedade. A autora nos apresenta, então, seu conceito de pedagogia decolonial como uma práxis propositiva que entrelaça o pedagógico e o decolonial, baseada em práticas, estratégias e metodologias que se constroem na resistência, na oposição e na insurgência dentro de/para lutas sociais, políticas, ontológicas e epistêmicas de libertação.

É nesse sentido, Janaína, que todos vocês nos propõem matemática(s) decoloniais: matemática(s) que se produzem na diversidade, nas diferentes formas de conhecer e de estar no mundo, por meio de uma práxis propositiva e inclusiva que problematize, que se oponha e resista à imposição de um conhecimento que se apresenta como neutro e absoluto. Essa é a manifestação de (re)existência que insurge do poema de Felipe e dos gritos por liberdade de Alex, Davi, Vitória, Janaína e de tantos outros.

Janaína: Uma boa mudança no ensino seria buscar uma forma de incluir todas as pessoas, pois se todos nós somos diferentes e pensamos diferente, como podemos aprender da mesma forma? Um sistema de ensino que realmente ensine a todos seria bom. A educação é tão necessária, transformadora! Mas, a forma como é disseminada está adoecendo as pessoas. Está criando um ódio pela matemática, um medo que não deveria existir. Vamos parar de entulhar 40 pessoas dentro de uma sala e ficar ensinando Bhaskara. "Bora" mostrar a importância dela em um lugar mais amistoso. "Bora" acabar com essa hierarquia absurda entre professor e aluno. Precisamos dar mais importância às matérias de humanas. Precisamos parar de pressionar alunos e defini-los por suas notas. Somos apenas adolescentes. Nossas emoções não estão completamente formadas. Não temos forças para continuar aguentando essa tortura mental. O problema não é e nunca foi a matemática. O buraco é mais fundo.

(Trecho das redações dos alunos da escola básica, 2017-2018). 


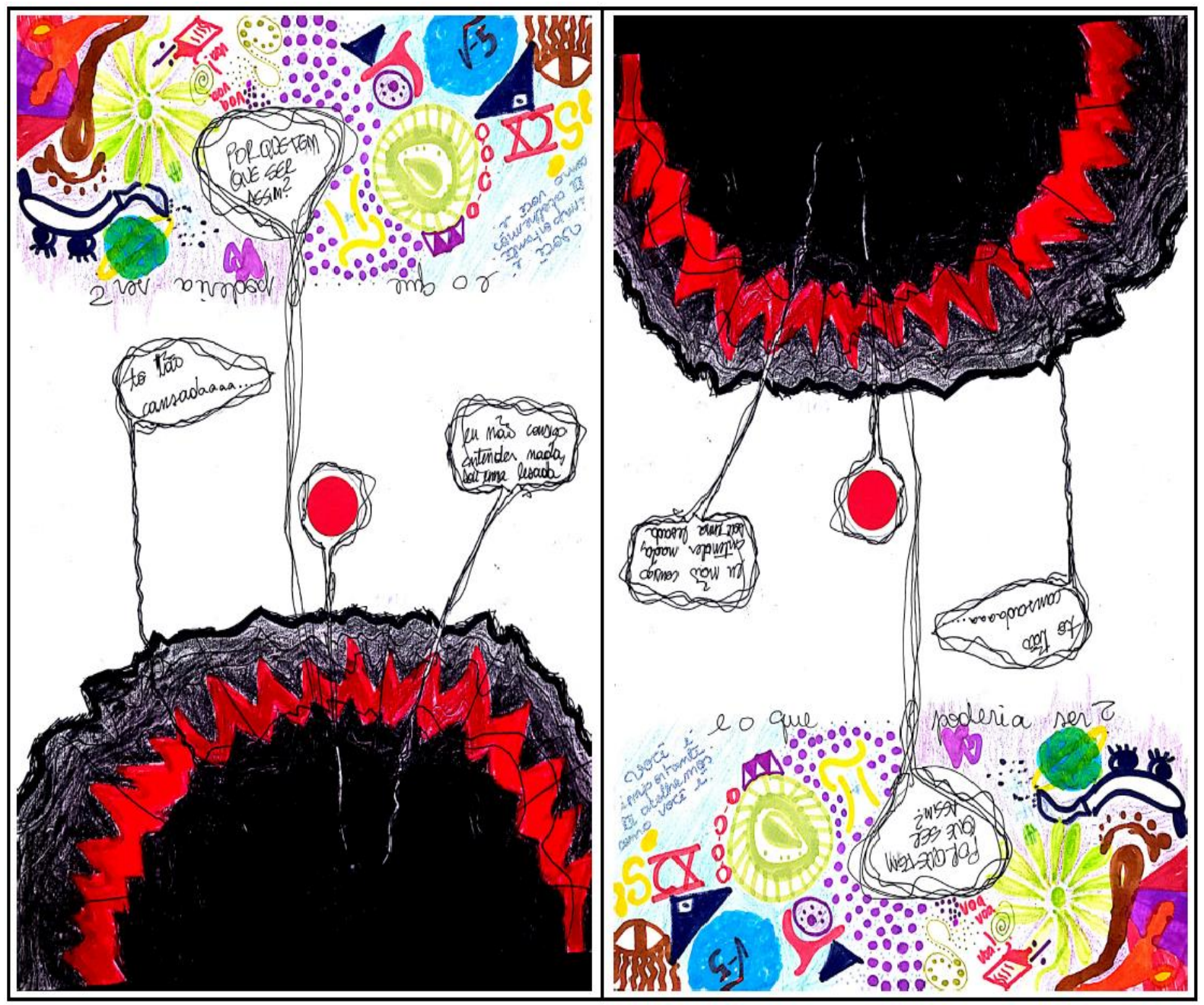

Figura 4 - As matemática(s) e seu mundo, observados sob duas perspectivas Fonte: Dados da pesquisa (2019)

Seu desenho incorpora o que você diz, Janaína. Ele retrata dois mundos que situam, em oposição, maneiras distintas de se apresentar as matemática(s) na escola. Observando esses mundos da perspectiva apresentada na figura à esquerda, vemos um lugar sombrio, sob trevas, de onde vozes tentam ecoar fora desse mundo para serem ouvidas em outro lugar: "Por que tem que ser assim? Eu não consigo entender nada, sou uma lesada. Tô tão cansada.”. É possível associar esse mundo sombrio ao lugar ocupado por pessoas subalternizadas pelas matemática(s) e às vozes que ecoam daqueles que resistem nesse lugar. $\mathrm{O}$ imaginário de um mundo no qual as matemática(s) coloniais excluem e são opressivas também é idealizado na própria fala de Janaína, ao descrever que o ensino de matemática(s) nas escolas está "adoecendo", "criando ódio", "criando medo". Imaginário construído a partir de um sistema de notas que rotula e estratifica os estudantes, "torturando (não somente) suas mentes, mas, (sobretudo), suas emoções que não estão completamente formadas".

Embora sua fala nos traga essa dramaticidade, Janaína, seu grito por liberdade é afirmativo e propositivo. Ele resiste a esses sentimentos inspirando-se na mensagem inclusiva 
do Cacique Raoni, que nos lembra que "respiramos todos um só ar, bebemos todos a mesma água, vivemos todos em uma só terra". Carregando esse sentimento, vemos, na figura à direita, esses dois mundos de outra perspectiva. Revela-se, agora, um lugar colorido, onde a diversidade de formas é visível e convive em harmonia, que nos mostra "como poderia ser" um mundo cuja existência quer repetir: "Você é importante. Te acolhemos como você é".

Não há nada mais a ser dito. Dialogando com a pedagogia decolonial de Wash (2017), essa é a potência das matemática(s) decoloniais que Janaína nos apresenta aqui neste lugar. Uma práxis propositiva que nos convida a agir nesse mundo: "Bora mostrar a importância (das matemáticas) em um lugar mais amistoso (e, sobretudo, mais acolhedor)". O termo "Bora", usado por Janaína, nos intima a agir - juntos - na construção de "um sistema de ensino que realmente ensine a todos", de maneira resistente, insurgente e em oposição a "um sistema de ensino que (seletivamente) ensine (apenas a alguns)". As vozes que ecoam desse lugar têm força para nos levarem muito longe.

Autóctones: Agora estamos aqui para revelar a vocês a beleza e a força, o que há de mais profundo e verdadeiro na nossa Tradição. $O$ ritual que aprendemos com nossos ancestrais na origem do tempo, a nossa herança. Que esta revelação possa despertar o encontro com a verdadeira natureza que está dentro de vocês, que possa fortalecer o espírito criador contra o avanço do lado obscuro. Estamos fazendo um ritual de passagem para transformar este lugar num país onde nosso povo possa permanecer vivendo com sua identidade e patrimônio, dentro de sua tradição. Onde nossos filhos e os seus filhos possam conviver de uma forma mais justa e respeitosa, compartilhando o conhecimento e a sabedoria, construindo um jeito novo de viver. (Autóctones das etnias Xavante e Mehinaku, 2000).

O ritual de passagem que está sendo preparado pelos donos da terra nos revela "o que há de mais profundo e verdadeiro na nossa Tradição", mas também nos lembra que chegou a hora de irmos embora, de voltarmos ao nosso chão. Tocados por esse momento, nos transportamos com a promessa de que não deixaremos esse lugar para trás. Seja atuando em fissuras, rachaduras ou em outros entrelugares, faremos ecoar esse canto "bravo e forte" como parte de nossa (re)existência e de nossa práxis, "construindo um novo jeito de viver" e, principalmente, fortalecendo nossa luta por matemática(s) decoloniais. Essas são as vozes que vêm da escola!

\section{Referências}

BARBOSA, J. C. Formatos insubordinados de dissertações e teses na Educação Matemática. In: D’AMBROSIO, B. S.; LOPES, C. E. (Orgs.). Vertentes da subversão na produção científica em educação matemática. Campinas: Mercado de Letras, 2015. p. 347-367.

BHABHA, H. K. O local da cultura. Belo Horizonte: Ed. UFMG, 1998.

BISHOP, A. Enculturacion Matemática: La Educación Matemática desde una perspectiva cultural. 
Barcelona: Editora Paidós, 1999.

COCHRAN-SMITH, M.; LYTLE, S. L. Inquiry as stance: practitioner research for the next generation. New York: Teachers College Press, 2009.

CRESWELL, J. W. Projeto de Pesquisa: Métodos qualitativo, quantitativo e misto. Porto Alegre: Artmed, 2007.

FANON, F. Pele Negra, Máscaras Brancas. Salvador: EDUFBA, 2008.

GIRALDO, V.; FERNANDES, F.; MATOS, D; QUINTANEIRO, W. Formação de professores para ensinar matemática em uma perspectiva decolonial. In: TRALDI, A.; TINTI, D. S.; RIBEIRO, R. M. (Orgs.). Formação de Professores que Ensinam Matemática: Processos, Desafios e Articulações com a Educação Básica, São Paulo: SBEM-SP, 2020.

GIRALDO, V.; MATOS, D.; QUINTANEIRO, W. A Construção de Subjetividades Profissionais na Formação Inicial de Professores de Matemática(s): Afirmando Posições Decoloniais contra Discursos de Subalternização da Profissão Docente. Perspectivas da Educação Matemática, Campo Grande: UFMS, v. 14, n. 34, p. 1-27, mar. 2021.

LARROSA, J. Notas sobre narrativa e identidade (A modo de presentación). In: ABRAHÃO, M. H. M. B (Org.). A aventura (auto)biográfica: teoria e empiria. Porto Alegre: EDIPUCRS, 2004. p. 1122 .

LEGGO, C.; SAMESHIMA, P. Starling stories: fiction and reality in education research. In: REID, A. D.; HART, P.; PETERS, M. A. (Eds.). A companion to research in education. Dordrecht: Springer, 2014. p. 20924-21336. Kindle version.

LÖWY, I. Ciências e gênero. In: HIRATA, H. et al. (Org.). Dicionário crítico do feminismo. São Paulo: Editora UNESP, 2009. p. 40-44.

MALDONADO-TORRES, N. Sobre la colonialidad del ser: contribuciones al desarrollo de un concepto. In: CASTRO-GÓMEZ, S.; GROSFOGUEL, R. (Coords.). El giro decolonial: reflexiones para una diversidad epistêmica más allá del capitalismo global. Bogotá: Siglo del Hombre Editores/Instituto Pensar, 2007. p. 127-167.

MATOS, D. Experiências com Matemática(s) na Escola e na Formação Inicial de Professores: Desvelando Tensões em Relações de Colonialidade. 2019. 172f. Tese (Doutorado em Ensino e História da Matemática e da Física) - Instituto de Matemática, Universidade Federal do Rio de Janeiro, Rio de Janeiro, 2019.

MATOS, D. QUINTANEIRO, W. Lugares de resistência na formação inicial de professores: por matemática(s) decoloniais. Perspectivas da Educação Matemática, Campo Grande: UFMS, v. 12, n. 30, p. 559-582. 2019.

OLIVEIRA, L. F.; CANDAU, V. M. F. Pedagogia Decolonial e Educação Antirracista e Intercultural no Brasil. Educação em Revista, Belo Horizonte, v. 26, n. 1, p. 15-40, abr. 2010.

ORLANDI, E. P. Análise de Discurso: princípios e procedimentos. 8. ed. Campinas: Pontes, 2009.

PÊCHEUX, M. O discurso: estrutura ou acontecimento. 4. ed. Campinas: Pontes, 2006.

QUIJANO, A. Colonialidad del poder, eurocentrismo y América Latina. In: LANDER, E. (Ed.). La colonialidad del saber: eurocentrismo y ciencias sociales. Perspectivas Latinoamericanas. Buenos Aires: CLACSO, 2000. p. 201-246. 
TAMAYO-OSORIO, C. A colonialidade do saber: Um olhar desde a Educação Matemática. Revista Latinoamericana de Etnomatemática, San Juan de Pasto, v. 10, n. 3, p. 39-58, out. 2017.

WALSH, C. Interculturalidad, plurinacionalidad y decolonialidad: las insurgencias políticoepistémicas de refundar el Estado. Tabula Rasa, Bogotá, n. 9, p. 131-152, jul./dez. 2008.

WALSH, C. Interculturalidad, estado, sociedad: luchas (de)coloniales de nuestra época. Quito: Universidad Andina Simon Bolivar/Abya-Yala, 2009.

WALSH, C. Lo pedagógico y ló decolonial: entretejiendo caminos. In: WALSH, C. (Org.).

Pedagogías decoloniales: prácticas insurgentes de resistir, (re)existir y (re)vivir. Quito: Abya Yala, 2013. p. 23-68.

WALSH, C. ¿Interculturalidad y (de)colonialidad? Gritos, grietas y siembras desde Abya Yala. In: DINIZ, A. G.; PEREIRA, D. A. (Coords.). Poéticas y políticas da linguagem em vías de descolonização. Foz do Iguaçu: Universidad de Integración Latinoamericana, 2017. p. 19-53.

Submetido em 05 de Março de 2020. Aprovado em 05 de Janeiro de 2021. 